\title{
Transborder Cooperation of Border Regions in Ukraine and Hungary
}

\author{
Yeva Kish \\ Uzhhorod National University \\ 88 000, Uzhhorod, University str. 14, Ukraine \\ cross $^{\text {ref }}$ http://dx.doi.org/10.5755/j01.ppaa.17.1.20611
}

\begin{abstract}
The analysis of Ukrainian-Hungarian transborder cooperation has been made, the problematic issues have been determined together with the possible ways of conducting reforms and changes in the context of forming an integral Ukrainian-Hungarian transborder region. The role of transborder cooperation in the system of international relations as well as in the context of developing logistic infrastructure in the social and economic development of border regions of Ukraine and Hungary has been analysed. The main directions of the development of the border region are: making use of the possibilities of the favourable geographical and geopolitical location of the region, development of tourism, intensification of international transport corridor, formation of an international logistic cluster.
\end{abstract}

Keywords: Ukraine, Hungary, European Union, Transcarpathia, border region, transborder cooperation, state policy, logistics.

Raktažodžiai: Ukraina, Vengrija, Europos Sajunga, Užkarpatè, pasienis (pasienio sritys), tarpvalstybinis bendradarbiavimas, sritis (regionas).

\section{Introduction}

The place and role of transborder cooperation in the modern system of international relations should be viewed in the context of strategic national and state interests, foreign political actions directed at maintaining and realization of these interests. In the context of realizing foreign policy both for Ukraine as a non-EU member, and its western neighbours, EU member states, Central European countries, an effective transborder policy is to be realized. It is of special importance for Ukraine as far as reaching European standards in transborder cooperation will enhance the European integration process. Thus, the issues of transborder cooperation of Ukraine's regions with immediate neighbouring countries - Central European countries, e.g. Hungary in the context of expanding European integration require substantiation and are of special scientific interest. 
A comprehensive research of this issue is highly topical as far as in the dynamic interregional, transborder relations one can see new tendencies of interrelations and interferences of global, continental and subregional integration processes, intergovernmental and interregional relations, relations between the centre and the regions in separate countries, decentralization of power and wider jurisdiction on regional and local levels. In other words, we are talking about a specific aspect of further intensification of the process of democratization of international relations and internal development at the stage of systematic social transformation that Ukraine is going through at the beginning of XXI century. Thus, researching the issue of Ukraine's foreign policy at the regional level, in the Central European region, to be exact, is of utmost importance and is highly topical both in theory and practice of Ukraine's Eurointegrational process.

Nowadays, transborder cooperation in Europe and in Ukraine are at the stage of systematic qualitative changes. Within the expanded European Union, developed transborder cooperation has entered an active stage as a result of substantial decrease of barriers on the internal EU borders and is becoming a means of successful realization of commmon regional policy, subsidiarity principle, decentralization of power, etc., and in a wider sense - building an integrated "Europe of regions".

After expansion of the EU to the East and entrance of the Central European countries to the EU, Ukraine's transborder cooperation with the Central European countries entered a qualitatively new stage of development. All the member parties do have the political will and aspiration for close transborder cooperation and a new mechanism of cooperation. Recent years saw a significant improvement of the normative basis of regulating international relations of Ukraine's transborder cooperation with Central European countries - new EU members. Of special importance in the development of international legal and national system of regulating transborder relations was the approval and enforcement in Ukraine of the 2004 Law "On transborder cooperation" and ratification by the Cabinet of Ministers of Ukraine of the State programme of developing transborder cooperation for 20162020.

\section{Theoretical and legal foundations}

Two subsystems form the organizational and legal mechanism of regulating the system of Ukrainian-Hungarian transborder cooperation: international-legal and civillegal. Pan-European norms and principles fixed in EC documents form the foundation for the development of international relations of Ukraine's transborder cooperation with Hungary. The main document that legalizes these relations and enhances decentralization of making decisions by the regions' authorities is the European Framework Convention on transborder cooperation between territorial communities or the government (ETS No106) - Madrid, 21 May 1980, as well as additional protocols giving more power to the regions in foreign economic and political issues, foster regions' international activity and positive discrimination of peripheral border territories (European Framework Convention, 1980). As a result of ratification of 
Madrid Convention (on 21 May 1980) by the Supreme Council of Ukraine (the Verkhovna Rada) in 1993, its provisions (international legal norms concerning transborder cooperation specified by the Convention) became part of the national legislation of Ukraine and have priority over internal laws in compliance with article 27 of the 1969 Vienna Convention on the law of international treaties.

According to Article 2 of the Convention: In this convention "transborder cooperation" shall mean any common actions directed at intensifying and deepening of good neighbourly relations between territorial communities of the authorities that are under the jurisdiction of two or more Contracting Parties, as well as concluding any agreements that might be necessary or reaching arrangements". Additional protocol (ETS No159) to the European Framework Convention that entered into force on 1 December 1998 strengthens the Framework Convention by clearly determining the right of territorial communities to conclude treaties on transborder cooperation on particular terms by determining the validity for the national legislation of acts and resolutions passed within the framework of agreements on transborder cooperation, as well as by determining the legal capacity (the status of a "legal entity") of any body established hereunder. The second protocol to the European Framework Convention concerning inter-territorial cooperation (ETS No169) signed on 5 May 1998 is aimed at establishing the legal framework for the development of mutual relations of transborder cooperation of the authorities by enabling them to conclude agreements on cooperation with territorial communities or authorities of other countries in the context of the development of inter-territorial cooperation (mutatis mutandis). Therefore, the Framework Convention together with additional protocols form the legal grounds of transborder cooperation of European countries' regions, including Ukraine and Hungary.

Discussions. Nowadays both Ukrainian and Hungarian scientists, specialists in the field of international relations pay great attention to the issue of transborder cooperation between Ukraine (Mikula, 2006; Kiss, 2003, 2004, 2008) and Hungary (Zsuzsa, István, 2002; István, 2008). In science and practice there are no unified "rules" of forming and building up Euroregions, moreover, there is no generally accepted notion. The historical experience of forming and developing Euroregions in the XX century proved that their aims, means, directions, and tasks changed serving the achievement of concrete pragmatic aims.

Taking into account the fact that the author has analysed a great number of researches on the issue of transborder cooperation, Euroregions, the study of Euroregions in home science can be divided into two concrete segments. First of all, (unfortunately, refers to the majority of publications) home researchers and experts idealize the experience of Euroregions in Ukraine. Simplified description of the experience of Euroregions in Ukraine together with artificial combination of transborder cooperation of intergovernmental and interregional levels aimed at presenting "best practices" of such a transborder cooperation of Ukraine downplays the research problems and shows lack of understanding of the essential characteristics of the Euroregions' activities. Secondly, the advantages include the first scientific 
academic economic researches accumulating the European Euroregions' experience and determining concrete problems and pragmatic recommendations as to their building up on the Ukrainian border.

This article is a logical continuation of the problematic issues of developing transborder cooperation in Ukraine. The aim of using an integrated and systematic approach to the research is to single out the main factors in the formation of Euroregions that enable one to elaborate in theory and implement in practice an effectively functioning model of Euroregions in Ukraine (Kiss, 2003, 2004, 2008, 2009).

A number of researches of Ukrainian scientists deal with the issue of European regional policy and its various dimensions. First of all, we should mention monographic researches, publications of the Institute of regional researches focusing on economic issues (Mikula, 2003, 2004). Scientific publications of the Institute EastWest are also noteworthy for they study issues of Ukraine's Euroregional policy in comparison with analogical processes in Central and Eastern European countries (Regional policy, 2000; Way to Europe 2000). Moreover, scientific investigations of the Institutes's experts realize "the best practice" of European regional policy. We would also like to emphasize the importance of studying the European experience in the issue of Euroregional development and Euroregional integration.

However, too little attention is paid to the issue of real practical adaptation of principles and mechanisms of Euroregional policy in Ukraine under new geopolitical conditions on the European continent. It is conditioned by a kind of failure to understand the systematic character of transborder cooperation. In other words, some scientists do not consider transborder cooperation to be part of regional policy. Moreover, there is some confusion about the categories "border cooperation" and "transborder cooperation".

\section{Methodology}

By using the methodology of functional analysis and analogy, comparative analysis of the systematic research of transborder cooperation and Euroregions we will dwell on the essence and experience of transborder cooperation. The experience of Euroregional transborder cooperation in Ukraine has to be adopted as a basis, however, not in the sense of copying for it is impossible due to the specific character of general regularities of Euroregional cooperation in Europe.

Systematic approach to the research of Euroregions. Formation of a new subsystem of international relations between Ukraine and Central European countries (full members of the EU), as well as the ever closer EU borders near Ukraine's western borders conditions the necessity to systematically study the new status of Euroregions on the new Eastern borders of the EU. Especially important for Ukraine is the process of transforming essential characteristics of Euroregions after the expansion of the EU to the East. In fact, Euroregions play the key role in the formation of Ukraine's effective system of transborder cooperation.

A certain reaction to the "presentation" of the activity of quasi-successive 
Euroregions in Ukraine usually idealized their role, significance, and the tasks. A detailed analysis of the documents on the establishment of Euroregions in Ukraine, with determined aims and tasks, clearly shows the unfortunate non-correspondence of reality to the previously set aims and tasks. Certainly, we cannot speak of the zero effect of their activity for some partial successes of a non-systematic character were present, mainly in the cultural sphere with the financial support of EU funds; the necessity to implement comprehensive social and economic projects and programmes is only mentioned in the regulations. Occasional success with its bulky structural components failed to form an integral system of Euroregions. Provided the funding is limited, their efforts are directed at celebrating Euroregion jubilees or imitating effectively functioning models of Euroregions in Ukraine.

\section{Results}

In the development of transborder cooperation between Ukraine and Hungary of special importance are the bordering regions: Transcarpathian region (Ukraine) and Szabolcs-Szatmár-Bereg County (Hungary). Transcarpathian region, as one of Ukraine's bordering regions, lies at the point of intersection of Ukrainian state border with 4 European countries: Poland, Slovakia, Hungary and Romania; Transcarpathia's neighbour Szabolcs-Szatmár-Bereg County (North-East region of Hungary) borders on the administrative and territorial units of 3 countries: Slovakia, Ukraine, and Romania, allowing them to conduct multilateral transborder and Euroregional cooperation on the interregional level (Kárpátalja, 2009, p. 458).

An institutional form of transborder cooperation is Euroregions - bilateral and multilateral international associations and unions of border administrative, territorial units of Ukraine and Hungary, as well as of other Central European countries. At the initiative of Hungarian and Ukrainian border regions, border administrative and territorial units of Ukraine, Hungary, Poland, Slovakia, and Romania in February 1993 established the international association Carpathian Euroregion (with the territory of $132651 \mathrm{sq}$. $\mathrm{km}$. and the population of 14 million people) that is an organizational form of transborder cooperation of the European type and serves an example of Ukrainian-Hungarian transborder cooperation on a multilateral basis.

The Ukrainian part of the Euroregion (area - $56660 \mathrm{sq}$. km.) is represented by four regions in Western Ukraine: Transcarpathian, Lviv, Ivano-Frankivsk, Chernivtsi. The Hungarian part of the Euroregion (area $-28639 \mathrm{sq} . \mathrm{km}$.) consists of five counties (megye), situated in the North-Eastern part of Hungary: Szabolcs-Szatmár-Bereg, Borsod-Abaúj-Zemplén, Hajdú-Bihar, Heves, Jász-Nagykun-Szolnok, as well as cities: Nyíregyháza, Miskolc, Debrecen, and Eger (Közös múltunk, 2014).

Generalizing the activity and development of the Carpathian Euroregion, it should be noted that this period of time is too short for the development of such an association as the Carpathian Euroregion. Even the European development of Euroregions testifies to the fact that a powerful economic development of border regions within the framework of Euroregions or the formation of transborder regions in Europe requires decades. However, it ought to be mentioned that the Carpathian 
Euroregion both in 1990s and nowadays - at the beginning of XXI century under new geopolitical conditions, should have had great geopolitical significance. However, due to a number of objective, organizational, internal and external reasons, we have to admit that the aims and tasks set out at the time of its foundation have not been completed as of today. And this is only one of the numerous drawbacks. It is clear that in those times under difficult international relations in the Central European region the optimal decision was to establish the Carpathian Euroregion at the initiative of the government (de facto political aims during the establishment of the Carpathian Euroregion dominated over the economic ones), thus, the Carpathian Euroregion was not established at the initiative of the regions, local communities or self-government bodies as it is accepted in Europe.

A model example of real strategically calculated transborder cooperation of the border region of Ukraine - Transcarpathia to be exact with the border region Szabolcs-Szatmár-Bereg (Hungary) is (the only along the western border of Ukraine) the document - Conception of common development of border territories of Ukraine and Hungary. With the aim of a comprehensive social and economical development of border regions of Ukraine and Hungary, with the help of local self-government bodies of Ukraine and Hungary, an integrated, scientifically substantiated and pragmatic Conception of common development of border regions and transborder cooperation of Ukraine and Hungary (Transcarpathia region and Szabolcs-SzatmárBereg county) was elaborated (Conception, 2003).

In this context, it would be plausible to mention the main directions of the development of Ukrainian-Hungarian border cooperation: building up a common border for Hungary and Ukraine as a high-priority direction of cooperation on the Ukrainian-Hungarian border; building up the zone of international transport corridors, participation in the development of European transport corridors, in particular of the fifth transport corridor Trieste-Ljubljana-Budapest-Lviv-Kyiv that is the most important element on the Europe-Caucasus-Asia route; environmental protection, prevention of transborder pollution, protection of ecosystems and water resources from pollution, gradual implementation of EU norms (Water Framework Directive) for rational water use in the Tysa river basin; Cooperation in the development of a tourist recreational complex, development of various forms of tourism, namely: medicinal, curative, route identification (highland ecotourism, rural), sports (mountain skiing) and the necessary infrastructure; creation of the conditions, stimulation of the development of small businesses in the border regions, implementation of an informative network, database for searching partners, facilitating the development of industrial integration and cooperation in food and processing industry; facilitating the development of national minorities, making contacts, studying the experience of solving national problems and organization of national minorities' self-government, maintaining their cultural and educational needs. 


\section{The main principles and aims of developing the Ukrainian-Hungarian border territory}

Taking into account internal resources, national conceptions of territorial development under the conditions of applying the main EU principles the following general aim was formulated that determines the foundations of the development strategy. The general aim of the Ukrainian-Hungarian border region can be formulated in the following way: economic development of the Ukrainian-Hungarian border territory, fostering social organization, improvement of the quality of living of the population living there under the conditions of maximal use of the possibilities offered by transborder cooperation.

The general aim determines that the final aim of the development lies in the stimulation of transborder cooperation, as well as maintaining conditions for cooperation. Improvement of the relevant quality of life of the population is the main condition of a competitive economy that, taking into account current and future changes (as a result of Hungary's entrance to the EU) in the economic policy, can significantly support the border region taking into account the favourable geopolitical location of the region and its role as an international bridge between East and West. At the same time, intensification of social unity is possible, first of all, if traditional, natural and cultural values of the border region are preserved.

According to the Conception of common development of border regions, one can determine the following long-term aims that substantiate the priorities and measures to guarantee the development of the border region. The aims are: creation of a socially and economically clear-cut region, intensification and acceleration of the processes functioning in the region; strengthening of transborder economic and social relations, giving an effective systematic character, coordination of local and central initiatives in the context of institutionalizing transborder cooperation; spreading positive priorities, characteristic of only one side of the border to the whole region, providing for the best positions in the macroeconomic sphere of economic and social networks; getting ready to use the advantages of future joining the EU, as well as regulation of the consequences of non-simultaneity of joining the EU of Ukraine and Hungary. To achieve the above-mentioned strategic aims five priorities of development were determined: development of economic cooperation; development of human resources, cooperation in culture, innovations, and scientific researches; development of transport and infrastructure, building up border crossing points; protection of nature and the environment; tasks outside the sector (Conception, 2003).

The 2007-2013 financial period expanded the possibilities of UkrainianHungarian transborder cooperation. In the period 2007-2013 within the framework of realizing the Program of transborder cooperation of Hungary-Slovakia-RomaniaUkraine we will only focus on the Ukrainian-Hungarian projects of transborder cooperation: "Administration of transborder destinations in the Transcarpathian region and Szabolcs-Szatmár-Bereg County" with the budget of $273177 €$; "The Carpathian tourist route" is trilateral, includes the Slovak region and has the budget of $480177 €$; "The Carpathian region as an attractive tourist destination" - a four-party 
project with the budget of $197729 €$; "The development of a common tourist strategy between Transcarpathia and Borsod-Abaúj-Zemplén county" with the budget of $408902 €$; "Historical facts on the common religious and cultural heritage of the Carpathian peoples and the problems of their preservation" with the budget of 273177 $€$; "Following Rákóczi's places of glory" is a trilateral transborder tourist route , includes the Slovak region and has the budget of $440899 €$; "An integrated system of bicycle tourist routes along the Ukrainian-Hungarian border" with the budget of $417158 €$; "Provision of conditions to create an international transborder Nature park" Szatmár-Bereg with the budget of $378020 €$. Noteworthy are the following large-scale projects that intensify the activity of transborder cooperation in the Transcarpathian region: "Drawing up documents to create a transborder industrial park with logistic elements "Bereg-Karpaty" (with the budget of $340358.00 €$ ); "Steady development of natural resources in the Tysa river basin" (with the budget of $1111500.00 €$ ); "Further development and harmonization of programs of flood-preventing measures in the Upper Tysa region" (with the budget of $961560.00 €$ ).

\section{Problematic issues and their possible solutions}

Let us determine the following principal provisions on the topical issues of transborder cooperation: 1) Absence of intensive state financing of transborder cooperation projects, development of Euroregions (by the way, the pragmatically drawn up Order of the Cabinet of Ministers of 29 April 2002 №587 that included the Programme of development of Euroregions has no effect whatsoever as of 2005). 2) Extremely poor efficiency of the available institutions (agencies, centres whose main aim is individual self-sustained development) both for the formation of a layer of European grant managers, and for the development of important, topical border projects fails to enhance the dynamic development of Euroregions in Ukraine. 3) Absence of a real programme of transformation of the available non-effective Euroregions in Ukraine, their non-correspondence to the Euro-standards. It should be noted that all the critical comments on the activity of Euroregions in Ukraine expressed in 2003-2004 formed the basis of their institutional and functional changes. Even in the Eastern regions of Central Europe this period was marked by a clear segmentation of bulky and inefficient Euroregions. 4) The population of the Western Ukrainian border regions has no Euroregional identity. What we mean is absence of popularization of the idea of Euroregions in Ukraine when this identity failed to become immanent for the population of Ukraine's border regions (compared with peripheral and economically poorly developed Eastern regions of Central Europe).

The problem with Euroregions in Ukraine, to our mind, lies not only in the quantitative parameters, not to speak of their huge area, but mainly in their qualitative and systematic characteristics. A systematic approach to the development of Euroregions in Ukraine requires the realization of a number of economic, organizational and institutional factors to build them up. Of special importance in this context is the elaboration of special comprehensive programmes of developing Euroregions in Ukraine after the expansion of the EU to the East with the application 
of systematic approaches and Euroregional standards.

It is a fact that the activity of Euroregions in Ukraine was not ready for the expansion of the EU and the direct approach of EU borders to Ukraine. Euroregions in Ukraine could not adapt to the new conditions of functioning after the Central European countries entered the EU. Moreover, the present Euroregions failed to go beyond the framework of predominantly declarative and political cooperation. Therefore, the system of Euroregional and transborder cooperation in Ukraine needs systematic qualitative transformation.

The state programme of developing transborder cooperation for 2016-2020 states that the development of transborder cooperation in Ukraine is one of the high-priority tasks of realizing state regional policy (State programme). According to the document, the main problems of transborder cooperation, just like in previous years, include insufficient tempo of social and economic development of Ukraine's border regions as well as underdevelopment of instruments maintaining its realization. There are a number of other factors as well as organizational and legal drawbacks that negatively influence and hinder the development of transborder cooperation, namely: 1) a poorly developed border transport infrastructure, in particular motorways to state border checkpoints, bridges and car-ferries; 2) slow tempo of introducing modern methods of control at state border checkpoints; 3) legislative and institutional limitations on the development of small and medium-sized businesses in the border regions of Ukraine; 4) absence of a common (with other countries) system of notification about natural disasters and protection from emergency situations, as well as rational use of natural resources; 5) low level of using the tourist potential of the border regions and the cultural heritage; 6) declarative character of common priorities of intergovernmental cooperation, imperfect mechanism of common planning, as well as limited instruments of realizing common transborder cooperation projects together with neighbouring countries; 7) different rules and procedures of preparing and financing transborder cooperation projects; 8) low activity of the members of transborder cooperation at the level of districts and territorial communities; 9) absence of a visa-free regime for the population to travel on the territory of transborder regions, insufficient traffic capacity of the state border checkpoints to the needs of developing transborder cooperation; 10) unequal access of Ukrainian participants to the financial resources within the framework of realizing common programmes with the EU member countries on transborder cooperation as well as Strategies of the European Union and the Danube region; 11) insufficient amount of donor support of transborder cooperation projects in Eastern and Central regions of Ukraine that causes unequal conditions and low level of awareness of the level of transborder cooperation (State programme).

According to the Programme, the priorities of transborder cooperation with Hungary, including in the field of Euroregions, are: providing for the development of flood-prevention measures, formation of a system of flood forecast; providing for the development of tourist routes, especially bicycle and foot (pedestrian) routes; improving the quality of water; stable use of natural resources, especially water 
resource management, forestry; environmental protection, including the evaluation of risks and minimization of the negative consequences of influences caused by manufacturing activity on salt mines in the village of Solotvyno in Tyachiv district of the Transcarpathian region; providing for the development of entrepreneurship; experience exchange with the Hungarian Party on energy efficiency and energy saving; cooperation between educational establishments; conclusion of the project "Effective and safe border between Hungary and Ukraine".

Extremely simplified understanding and as a result inefficient formal realization of transborder cooperation in Ukraine did not form an integral system of transborder cooperation with clear-cut bi- and multilateral main directions, forms, kinds, and scientifically elaborated mutually advantageous concrete transborder programmes and projects for common realization. However, in the systematic plane UkrainianHungarian transborder cooperation is one of the most active forms of European-type transborder cooperation.

We can see the challenge in the development of transborder cooperation between Ukraine and Hungary in the XXI century in the formation of transborder cooperation in Ukraine as a dynamic and effectively functioning system via a comprehensive development of regions as well as intensified participation in international integration processes. We consider that by realizing EU regional policy (its main principles) Ukraine will get substantial assets from the EU Funds that will strengthen the innovative ability of Ukrainian regions in the future and will help achieve the first positive results on the way to European integration of our country.

The analysis of the status and significance of regions in Europe, as well as in the structure and policy of the European Union as of today, testifies to the fact that European regions are gradually becoming real subjects of international relations. One of the famous regionalists M. Keating rightfully claims, "it is now that regions after a period of quite a naive imitation can study and adapt each other's experience to their own institutions, traditions, cultures and problems" (Keating M. 1995). Of special importance in this sense is the experience of transborder and interregional cooperation - as the possibility for the European regions to make use of the advantages from the crreation of common economic transborder regions.

The essence of adaptation of Euroregional policy in Ukraine lies, first of all, in the realization of the main principles of European regional policy. The EU regional policy classification determined the following basic criteria: subsidiary character, decentralization, partnership, programming, concentration, and additionalism. Subsidiarity - is a public and political principle according to which higher social units have the right and have to solve only those problems that the lower structures are unable to perform - as the basic principle since the treaty on the European Union was concluded, is at the peak of its development. Decentralization - redistribution of powers aimed at their effective use and stimulation of regional initiatives, optimization of practical solution of issues at the regional level, as well as separation of functions and powers between different administrative levels of the EU. Partnership is cooperation between subjects of different levels (EU, state, region) of 
territorial and administrative units from the time of determining the aim to the complete realization of a concrete project. This principle is based on the condition that the activity and the development of regions can only be performed (the principle of subsidiarity is realized at the same time) when cooperation subjects constantly cooperate to achieve a common aim. Programming presupposes generation of development strategies on the basis of partnership taking into account high priority long- and short-term targets. In the EU regional policy the partnership principle determines the priority of investing not separate projects or actions, but programmes that have serious influence on the whole region. Realization of principles of concentration and additionalism means that the financial resources that the EU gives to member states or subjects of territorial, regional development have to be supplemented from local financial sources. In fact, these two principles have a complementary character, their main condition is cooperation and efficient application of principles, search and development of their own sources of financing regional development sources (Kiss, 2002).

The issue of Euroregional cooperation of border regions of Ukraine and its closest neighbours - Central European countries from the pragmatic point of view is the following - will the border regions of Ukraine be able to use the so-called advantages of peripheral character under new geopolitical conditions. However, the question is whether Ukrainian regions are ready to join effective mutually advantageous cooperation with European regions according to European standards and criteria or it is necessary to build up institutional foundations of Euroregional policy in Ukraine.

\section{The innovational potential of managing transborder cooperation of Ukrainian and Hungarian regions}

Transborder cooperation between Ukrainian and Hungarian regions in early XXI century is determined by the development and application of modern innovation mechanisms and principles. One of the ways to increase competitiveness of border regions is the application of clusters. Cluster approach is one of the most optimal mechanisms of increasing social and economic development of the neighbouring countries' periphery. Nowadays the transport and logistic activity, cooperation in the Ukrainian-Hungarian border region is of utmost significance for the development of transborder cooperation. Formation of clusters in the Ukrainian-Hungarian border region is an efficient means of development of innovational activity of border regions in Ukraine and Hungary. Moreover, this testifies to the use of competitive advantages by Ukraine and Hungary and the formation of a European level transborder logistic cluster.

Integration of Ukraine's transport and road complex into the European and world transport systems requires the formation of a national network of transport corridors within the system of international ones, as well as the development of logistic centres, the formation of logistic clusters in the border regions that are the main structures in the system of international haulage. By using their favourable geopolitical location, 
border regions of Ukraine and Hungary can not only increase the amount of transit freight, but also form new institutional forms and mechanisms to form a branched network of component systems of international transport corridors. The fifth transport corridor that unites Southern European countries via the territory of Ukraine achieves the Trans-Siberian Railway (Russia), thus uniting Western Europe with the Far East and China, crosses the state border of Ukraine and the Transcarpathian region. On the Hungarian side there is the international logistic centre Záhony built with the participation of Russia, Hungary, and Ukraine. In the transborder region, covering the Hungarian Szabolcs-Szatmár-Bereg county, the Ukrainian Transcarpathian region, the Slovak Košice Region and the Satu Mare county in Romania and uniting railway, automobile, air, river transport, of utmost importance is logistics.

The possibility of forming a transborder transport and logistic cluster in the border territories of Ukraine and Hungary is of utmost importance for on the territory of Hungary in the Záhony border region there is a logistic centre with traditionally developed Ukrainian-Hungarian trade, economic, and expeditionary relations that form a strong basis for the formation of transborder transport and logistic cluster. It is clear that first of all it is necessary to form a transportation and logistic cluster on the territory of Transcarpathia.

The main component of the transportation and logistic cluster in Transcarpathia should become an international transportation and logistic centre (ITLC). The international transport and logistic centre will become the operator of export-import and transit freight traffic and in a unified centre, on the basis of general information sphere it will be able to guarantee efficient integrated logistic service of shipping and processing processes as well as of customs, brokerage and concomitant services. In fact, the international transportation and logistic centre (ITLC) in Chop (Transcarpathian region, Ukraine) can become a unifying body to control intermodal transportation on the Western border of U, whose offices should be located in Záhony (Hungary), Čierna nad Tisou (Slovakia), powerful international trade and transport centres - intersections of transport traffic from Europe to Asia and vice versa (Concepcion of ITLC, 2007).

The availability of a powerful transport hub Chop-Mukachevo-BatyevoUzhhorod, the passage of the 5th (Cretan) international transport corridor (TriesteLjubljana-Budapest-Bratislava-Chop-Lviv) conditioned the fact that Transcarpathia is one of the most attractive international border transportation hubs in Ukraine for the arrival of transnational corporations.

Formation of a logistic cluster in Transcarpathia can interest transnational corporations as to their participation in the process in case the strategy of territorial government bodies is professionally elaborated, concrete in space and time, is in compliance with the transnational corporation's interests to get reliable, quick and qualitative logistic services, use technologically highly developed communication infrastructure, namely, international air communication, including the use of general purpose aviation that would maintain the work of companies without hours-long waiting time at border crossing points that would in its turn lower the cost price of the 
transnational corporation's products. Only in this case transnational companies will participate in the formation of a logistic cluster on the territory of Transcarpathia, until then they will make use of their own logistic departments spending substantial funds on their maintenance (Concepcion of logistic claster, 2007).

The availability on the territory of the Transcarpathian region bordering on four European countries of one of the biggest border transportation complexes, 6 international and 4 intergovernmental railway and automobile crossing points, an international airport as well as the possibility to develop river transport objectively makes Transcarpathia a natural transit bridge between Europe and Asia. The main aim of developing this sphere is the improvement of the economic potential of the region in general. This can be performed by taking into account two tendencies: by using the favourable location of the region, the development of transport routes and service infrastructure of the transit traffic on the one side, and the improvement of the economic situation in the region by means of developing local infrastructure on the other.

The geopolitical position of the Transcarpathian region and EU transport policy provide for an intensive traffic of motor transport, transit by rail freightage and that requires extension of the network, increased quality of technical infrastructure of communication, service and information provision. Expansion of the EU to the Ukrainian borders as well as new member countries in the Schengen zone conditioned the increased significance of a number of factors: 1) regional EU policy covered Western regions of Ukraine and they were governed by new instruments of the Programme of EU neighbourhood; 2) the mechanism of action of EU regional policy by means of financial support of transborder projects from the Structural funds fosters the development and implementation of regional strategies of development not only for the border regions, but also of common conceptions of developing transborder regions, thus enhancing the implementation of new methods of territorial administration, increasing the standard of life of the population in the Ukrainian regions, etc.; 3) EU transport policy stipulates the intensification of building up communicative infrastructure and the introduction of new technologies and methods in the sphere of transport; 4) location of Ukraine between powerful Western and Eastern markets creates the conditions to form a powerful complex of international transportation that should be used under the conditions of ever increasing competition.

\section{Conclusion}

1. Nowadays there is a developed international legal contractual basis of Ukrainian-Hungarian transborder cooperation that complies with the European standards of transborder cooperation, creates a clear-cut legal framework and foundations for bilateral transborder relations as well as enables effective cooperation of border administrative and territorial units of Ukraine and Hungary. Moreover, the principles that are fixed in valid bi- and multilateral international legal acts are actively introduced into the practice of Ukrainian-Hungarian transborder relations. 
2. The directions and forms of Ukrainian-Hungarian transborder cooperation were formed first of all by means of expanding trade, economic, cooperation, production, scientific, technical, cultural and other relations of border administrative, territorial units and communities, realization of common investment projects, environmental protection programmes, measures for preventing natural and technological disasters, building up the border infrastructure, intensification of contacts in the humanitarian and other spheres on the interregional level. As a positive example of Eurointegrational, transborder cooperation of border regions of Ukraine and Hungary, one should mention the elaboration of an integrated and scientifically substantiated Conception of common development of border regions and transborder cooperation of Ukraine and Hungary (Transcarpathia region and Szabolcs-Szatmár-Bereg county).

3. The modern tendency of segmenting Euroregions on border territories of Central European countries takes place by means of creating bi- or maximum trilateral small but dynamic and pragmatic in aim and the character of development Euroregions with clearly defined economic aims. Singling out in this case the experience of Hungary, let us draw attention to the fact that the border territories in Hungary do have mainly bilateral Euroregions that are formed to improve the population's welfare, as well as for the economic development of the border regions. It is a fact that the following border regions of Ukraine and Hungary - Transcarpathia and Szabolcs-Szatmár-Bereg are the weakest regions in the social and economic indices of development in their own countries. In this case it is highly topical and pragmatic to form in this important geopolitical space a bilateral UkrainianHungarian transborder region.

\section{References}

1. István, S.-Z. Kárpátok Eurorégió 15 év a határokon átívelő kapcsolatok fejlesztéséért Debreceni Egyetem Kossuth Egyetemi Kiadója. Debrecen: 2008.

2. István, S.-Z. Közös múltunk-közös jövőnk, együtt Európáért: 20 éves a Kárpátok Eurorégió- emlékek, sikerek, megújulás. Debrecen: 2014.

3. Kárpátalja. Monográfia. 12 fejezet. - MTA RKK. Pécs: Dialóg Campus, 2009, 454-492.

4. Kiss, É. Az Európai Unió regionális politikájának jelenlegi prioritásai. A határon átívelő együttmüködés perspektívái. Nyíregyháza, 2008, p. 15-27.

5. Mikula, N. V. Ukraine's Trans-border Cooperation. Its State and Development Tendencies after EU Enlargement. New Challenges and Priorities in Trans-border Regional Cooperation of the Enlarged European Union. Uzhgorod: Lira, 2006, p. 62-63.

6. The European Union and the Regions. M. Keating, B. Jones (eds.). Oxford: Clarendon Press, 1995.

7. Zsuzsa, L., István, S.-Z. A Kárpátok Eurórégió együttműködés mérlege. Budapest: Eurotronik, 2002.

8. Zsuzsa, L., István, S.-Z. Együttmüködés és felzárkózás a Kárpátok Eurorégióban, Budapest: Stádium, 2002. 
9. Державна програма розвитку транскордонного співробітництва України на 20162020 роки. http:// www.zakon.rada.gov.ua [2017-11-10].

10. Свропейська рамкова конвенція про транскордонне співробітництво між територіальними общинами або властями від 21.05.1980 [Текст]. Oфiu. вicн. України 2006, 2006, Ст. 585. http://zakonl.rada.gov.ua [2017-11-18].

11. Кіш Є., Мікула Н. Концепція створення логістичного кластеру на Закарпатті. Ужгород, 2007, $70 \mathrm{c.}$

12. Кіш, Є. За програмою сусідства. Транскордонне співробітництво України після східного розширення Свропейського Союзу. Політика і час, МЗС України, 2004, №12, 27-34.

13. Кіш, Є. За стандартами транскордонної взаємодії. Політика $i$ час, МЗС України, 2003, №10, 79-84.

14. Кіш, Є. Концепція спільного розвитку прикордонних територій Украӥни $i$ Угорщини. Українсько-угорське транскордонне співробітництво: можливості та пріоритети у XXI столітті. Ужгород: Ліра, 2003.

15. Кіш, Є. Регіональна політика Європейського Союзу. Незалежний культурологічний журнал Ї, Львів, 2002, №23, 133-157.

16. Концепція спільного розвитку прикордонних територій України і Угорщини. Ужгород-Ніредьгаза: TOB “GFB”, 2003.

17. Концепція створення Міжнародного транспортно-логістичного центру (МТЛЦ) на території України. Свропейська спілка транспортників України. 2007, 32 с.

18. Мікула, Н. Єврорегіони: досвід та перспективи. Львів: ІРД НАН України, 2003.

19. Мікула, Н. Міжтериторіальне та транскордонне співробітництво. Львів, 2004.

20. На шляху до Європи. Український досвід євро регіонів, Інститут Схід-Захід, К.: Логос, 2000, 224.

21. Регіональна політика в країнах Свропи, Інститут Схід-Захід, Київ: Логос, 2000, 28 61.

\title{
Yeva Kish
}

\section{Tarpvalstybinis Ukrainos ir Vengrijos pasienio sričių bendradarbiavimas}

\author{
Anotacija
}

Straipsnyje nagrinejamas tarpvalstybinis Ukrainos ir Vengrijos bendradarbiavimas, išryškinant svarbiausius probleminius aspektus ir siūlant reformas bei permainas, reikalingas formuojant vientisą šalių pasienio sritị. Straipsnyje apžvelgiamas tarpvalstybinio bendradarbiavimo vaidmuo tarptautinių santykių srityje taip pat logistinès infrastruktūros kontekste. Kaip pagrindinès pasienio sričių vystymo kryptys išskiriamas palankios geografinès ir geopolitinès regionų padèties išnaudojimas, turizmo plètra, tarptautinio susisiekimo koridoriaus stiprinimas bei tarptautinio logistikos klasterio formavimas.

Kish Yeva - Doctor Habilitatus of Historian Science, Professor, Head of the Department of the Hungarian History and the European Integration of Uzhhorod 
National University, Director of Research Centre of European Integration and National Minorities.

E-mail.: kish.eva15@gmail.com.

Kish Yeva yra habilituota istorijos mokslų daktarè, Užgorodo nacionalinio universiteto, Vengrijos istorijos ir Europos integracijos katedros vedejja, Europos integracijos ir tautinių mažumų tyrimų centro direktorè.

E. paštas: kish.eva15@gmail.com.

Straipsnis įteiktas redakcijai 2017 m. gruodžio mèn.; recenzuotas; parengtas spaudai 2018 $\mathrm{m}$. vasario mèn. 